\title{
ULOGA VISOKO SENZITIVNOG C-REAKTIVNOG PROTEINA KAO NESPECIFIČNOG BIOMARKERA UPALE KOD DJECE S ASTMOM
}

\author{
ROLE OF THE HIGHLY SENSITIVE C-REACTIVE PROTEIN AS NONSPECIFIC BIOMARKER OF \\ INFLAMMATION IN CHILDREN WITH ASTHMA
}

\author{
Olivera Ljuboja, Jelica Predojević Samardžić, Dragana Malčić Zanić, Nina Marić
}

\begin{abstract}
Sažetak: Uvod: Astma je sindrom obilježen hroničnom inflamacijom disajnih puteva što predstavlja jedan od ključnih elemenata bolesti. Prema rezultatima dosadašnjih istraživanja u području alergologije, čini se da bi određivanjem nespecifičnog biomarkera upale visokosenzitivnog C-reaktivnog protein (hsCRP) bilo moguće procjeniti stepen inflamacije u disajnim putevima u bolesnika sa astmom, kako $u$ odraslih tako $i$ u djece. Dokazana je značajna korelacija između povećanja koncentracije hsCRP $i$ respiratornih simptoma, kao što su zviždanje $i$ dispneja nakon napora i noćnoga kašlja kod djece $u$ akutnoj egzacerbaciji astme

Cilj: Utvrditi da li nivoa hsCRP korelira sa težinom kliničke slike i dužinom asmatskog napada, i da li praćenje nivoa hsCRP može biti dobar pokazatelj (ne)uspješnosti terapije akutne egzacerbacije astme u djece.

Materijal $i$ metode: $U$ ispitivanje je uključeno 30-oro djece, uzrasta od 7 do 14 godina (dječaci $i$ djevojčice) hospitalizovane zbog liječenja akutnog napada astme. Liječenje je provedeno inhalatornom terapijom beta 2-agonista brzog djelovanja i antiholinergika, kod nepotpunog učinka na inicijalnu primjenu beta-2 agonista (umjereno teški ili teški napad) uključivani su sistemski kortikosteroidi. Za određivanje hsCRP uzet je serum bolesnika prije terapije i tri dana nakon terapije. Koncentracija hsCRP određena je imunoturbidimetrijskom metodom na lateks česticama na biohemijskom analizatoru Olympus AU 680.

Rezultati: Povišenu vrijednost hsCRP prvog dana je imalo 26,67\% pacijenata, nakon trodnevne primjene terapije povišene koncentracije hsCRP značajno su se smanjile kod njih 13,33\% u odnosu prema vrijednostima prije liječenja. Medijana vrijednosti hsCRP kod ispitanika sa teškom perzistentnom astmom statistički značajno veća nego kod pacijenata sa ostalim stepenima težine astme.

Zaključak: Rezultati ovog istraživanja su pokazali da su vrijednosti hsCRP u serumu kod pacijenata u akutnoj egzacerbaciji astme $u$ direktnoj korelaciji sa stepenom atopijskog statusa, što je viši stepen atopijskog statusa to su vrijednosti hsCRP bile više. Tom činjenicom naglašava se pitanje postojanja sistemske upale $u$ astmi kao bolesti koja prema definiciji podrazumijeva hroničnu inflamaciju disajnih puteva. Evidentno je da se hsCRP može koristiti kao nespecifičnog biomarker upale kod djece sa astmom, te kao pokazatelj uspješnosti terapije.
\end{abstract}

Ključne riječi: djeca, astma, hsCRP.

\section{UVOD}

Astma je sindrom obilježen hroničnom inflamacijom disajnih puteva što predstavlja jedan od ključnih elemenata bolesti. Za inflamaciju odgovorna je složena interakcija zapaljenskih ćelija i hemijskih medijatora, koji se mogu koristiti u dijagnostičke svrhe, predviđanje ishoda bolesti i u procjeni efikasnosti $i$ toksičnosti primjenjenih lijekova. Poznavanje posebnosti astme kod djece (klinička ekspresija bolesti, važnost alergije, nespecifičnih faktora $\mathrm{u}$ pokretanju simptoma $\mathrm{i}$ egzacerbacija astme), pravovremeno dijagnostikovanje i liječenje, važan su preduslov za rast i razvoj djeteta [1]. C-reaktivnog proteina (CRP) je tradicionalno određivan za postavljanje dijagnoze akutne inflamacije. Razvojem visoko osjetljivih metoda za određivanje hsCRP-a (engl. high-sensitivity $C R P$ ), čija donja granica detekcije 
iznosi od $0,1 \mathrm{mg} / \mathrm{L}$, je moguće određivati CRP u opsegu koji je niži od detekcionog limita konvencionalnih metoda, što je omogućilo njegovo korišćenje kod bolesnika sa hroničnim bolestima $[2,3]$. Budući da je inflamacija jedno od glavnih obilježja respiratornih alergijskih bolesti, ovim radom smo željeli ispitati da li povišene vrijednosti hsCRP, kao nespecifičnog biomarkera inflamacije, mogu da koreliraju sa in vivo i in vitro testovima koji se koriste u postavljanju dijagnoze astme, a što bi doprinjelo u predviđanju, diferencijalnoj dijagnostici, praćenju progresije bolesti i uspješnosti terapije na tok bolesti.

\section{CILJ RADA:}

Cilj rada je bio utvrditi da li nivoa hsCRP korelira sa težinom kliničke slike i dužinom asmatskog napada, i da li praćenje nivoa hsCRP može biti dobar pokazatelj (ne)uspješnosti terapije $u$ djece $u$ akutnoj egzacerbaciji astme.

\section{MATRIJA I METODE:}

Istraživanje je izvršeno prospektivno u periodu od jula 2013. godine do februara 2014. godine na Klinici za dječije bolesti u Banja Luci, u skladu sa Deklaracijom o ljudskim pravima. [4]. Svi učesnici ispitivanja su imali prije uključivanja u studiju pismenu saglasnost roditelja. U studiju je uključeno 30 djece, uzrasta od 7 do 14 godina (dječaci i djevojčice). Ispitivanu grupu činila su djece sa prethodno dokazanom alergijskom astmom, koja su se javila na Kliniku za dječije bolesti u Banjoj Luci sa simptomima kašlja i otežanog disanja, koji su trajali najviše tri dana prije javljanja u bolnicu. Po dolasku u bolnicu uzeta je detaljna anamneza i hetroanamneza (sa značajnim osvrtom na pozitivnu porodičnu anamnezu), učinjen je kompletan klinički pregled, određen je indeks tjelesne mase, izmjereni parametri vitalnih funkcija. Procjena plućne funkcije podrazumijevala je mjerenje vrijednosti forsiranog vitalnog kapaciteta (FVC) i forsiranog ekspiratornog volumena u prvoj sekundi (FEV1) izraženi u procentima, upotrebom Jaeger Master Scope spirometra (Jaeger $\mathrm{GmbH}$, Njemačka) standardizovanom procedurom. Uredan nalaz je podrazumijevao vrijednosti $\geq 80 \%$. Stepen težine astme je procjenjivan prema GINA smjernicama (5). Laboratorijskim analizama (kompletne krvne slike, C-rekativni protein) sključena je akutna infektivna bolest. U istom uzorku seruma određivani su i biomarker nespecifične imunosti (hsCRP) i vrijednosti ukupnog IgE. Nakon provedene dijagnostičke obrade djeca su primala odgovarajuću simptomatsku terapiju u trajanju od tri dana ( 72 sata), nakon čega je ponovo određivan nivo hsCRP.

Krv za analizu je uzorkovana iz periferne vene. Uzeta krv je centrifugirana 10 minuta na 3500 obrtaja/min. Jedan dio seruma $(200 \mu \mathrm{L})$ potom je zamrzavan na $-20^{\circ} \mathrm{C}$ do analize hsCRP. Koncetraciju hsCRP smo određivali imunoturbidimetrijskom metodom na lateks česticama, primjenjena je visokospecifična metoda za malo mjerno područje unutar referentnih intervala za djecu $<2,8 \mathrm{mg} / \mathrm{l}$, sve na biohemijskom analizatoru Olympus AU 680, sa reagensima Rosche proizvođača u centralnom laboratoriju Univerzitetskog KC Republike Srpske [81]. Kalibracija je izvršena pomoću orginalnog kalibratora (Olypmpus Serum Protein MultiCalibrator).

Koncentracija ukupnog IgE je određivana je fluoroimunohemijskom metodom sa monoklonskim i poliklonskim antitijelima, na analizatoru UniCAP sa reagensom istog proizvođača. Dobijene vrijednosti ukupnog IgE upoređivane su sa referentnim vrijednostima zavisno od uzrasta djeteta [6].

Početno liječenje astmatskog napada provodili smo kratkodjelujućim beta-2 agonistom (Salbutamol) za inhalatornu primjenu na 4, 6, 8 sati, zavisno od procijenjenog stepena težine astma napada. Kod težeg stepena napada primjenjivani su $\mathrm{u}$ kombinaciji beta -2 agonist $\mathrm{i}$ inhaltaorni antiholinergici. Kod nepotpunog učinka na inicijalnu primjenu beta-2 agonista (umjereno teški ili teški napad) uključivani su sistemski kortikosteroidi.

Podaci su analizirani upotrebom parametarskih i neparametarskih statističkih testova pomoću IBM SPSS Statistics programa. Statističkim značajnim smatrane su vrijednosti $p \leq 0,05$.

\section{REZULTATI}

Ovim istraživanjem je obuhvaćeno ukupno 30 djece sa postavljenom dijagnozom astme, od kojih je činilo 17 dječaka (56.67\%) i 13 (43.33\%) djevojčica. Prosječna starosna dob kod pacijenata je iznosila 127.77 mjeseci (95\% CI: 118.73 - 136.80). 
Perzistentna umjerena astma je bila prisutna kod 12 (40\%) pacijenata, njih $8(26.7 \%)$ je imalo perzistentnu blagu astmu 8 (26,67\%), dok je intermitentna i perzistentna teška astma bila prisutna kod $5(16,67 \%)$ pacijenata. Prosječan uzrast pacijenata sa perzistentnom umjerenom astmom je iznosio 122 mjeseca i 5 dana, dok je kod perzistentne teške astme iznosio oko 11 godina (131 mjesec). Perzistentna umjerena astma je bila najčešći oblik astme kako kod dječaka (41.18\%), tako i kod djevojčica (38.46\%). Djevojčice su imale više ispoljenu perzistentnu tešku astmu ( $23.08 \%) \mathrm{u}$ odnosu na dječaka (11.76\%). Ukoliko posmatramo udruženost astme $i$ drugih atopijskih bolesti (alergijski rinitis, atopijski dermatitis i nutritivnu alergiju) koje su dokazane kod pacijenata, uočava se, da od njih 30, 24 (80\%) ih je imalo alergijski rinitis udružen sa astmom, $12(40 \%)$ ih je imalo nutritivnu alergiju i astmu i $5(16,67 \%)$ su imali atopijski dermatitis $i$ astmu. Zastupljenost alergijskog rinitisa $\mathrm{u}$ odnosu na ostale atopijske bolesti je statistički značajno veća $(p<0.001)$, a takođe je utvrđeno da je zastupljenost atopijskog dermatitisa statistički značajno $(p=0.045)$ veća od zastupljenosti nutritivne alergije. Posmatrajući druge atopijske bolesti sa stepenom težine astme može se izvesti zaključak, da su pacijenti sa perzistentnom teškom astmom imali pridružene sve tri druge atopijske bolesti . Svi pacijenti sa teškom perzistentnom astmom imali pozitivnu porodičnu anamnezu (100\%). Prosječan broj alergijskih senzibilizacija na inhalatorne alergen (polen trave, polen korova, polen stabla, dermatophagoides pteronysinus, kućna prašina) se ne razlikuje statistički značajno u odnosu na strukturu pacijenata prema stepenu težine astme, međutim, upoređujući pacijente sa intermitentnom i teškom perzistentnom astmom uočavamo da je prosječan broj alergijskih senzibilizacija kod ispitanika sa teškom perzistentnom astmom statistički značajno veći nego kod ispitanika sa intermitentnom ( $p$ 0.030).

Medijana IgE kod svih pacijenata je iznosila $534.0 \mathrm{kU} / \mathrm{L}$ (IQ: $213.0 \mathrm{kU} / \mathrm{L}-805.0 \mathrm{Ku} / \mathrm{L}$ ), dok u odnosu na stepen težine astme vrijednosti IgE su statistički značajno veće u pacijenata sa teškom perzistentnom astmom ( $p$ 0.035).

Povišenu vrijednost hsCRP prvog dana je imalo $26,67 \%$ pacijenata, nakon trodnevne primjene terapije povišene koncentracije hsCRP značajno su se smanjile kod njih $13,33 \%$ u odnosu prema vrijednostima prije liječenja, ali su te vrijednosti još uvijek bile iznad referentnih predviđenim za uzrast. Medijana vrijednosti hsCRP kod ispitanika sa teškom perzistentnom astmom - $4.08 \mathrm{mg} / \mathrm{l}$ (IQ: 2.83 $\mathrm{mg} / \mathrm{l}-5.02 \mathrm{mg} / \mathrm{l})$ je statistički značajno veća nego kod pacijenata sa ostalim stepenima težine astme.

Pacijenti sa teškom perzistentnom astmom u odnosu na svaki drugi stepen težine astme su imali statistički značajno manju prosječnu vrijednost FVC i FEV1(Tabela 1), a utvrđena je i statistički značajna negativna korelacija povišenih vrijednosti hsCRP i plućnih funkcija ( Tabela 2)

\section{DISKUSIJA}

Brojna istraživanja pokazala su da je prevalencija astme viša kod dječaka nego kod djevojčica u prvoj deceniji života, dok sa porastom uzrasta dolazi do učestalije prevalencije kod ženskog pola, što je prema najzastupljenijoj teoriji posljedica uticaja hormonskog statusa na ekspresiju atopijskih bolesti $[7,8]$. Shodno našim rezultatima, i podaci iz dostupne literature pokazuju statistički značajniju učestalost astme u školskoj dobi, u prilog tome govori i najveća provedena Međunarodna studije za astmu i alergije u djetinjstvu (ISAAC) (9). U radu A b e r g a i E n g s t r ö m o v e praćen je prirodni tok atopijskog dermatitisa, alergijskog rinitisa $\mathrm{i}$ alergijske astme $\mathrm{u}$ 1335-oro djece do naveršenih 14 godina života. Zapaženo je da je $24 \%$ imalo znake dvije ili sve tri atopijske bolesti. Tako je $66 \%$ djece sa astmom imalo i alergijski rinitis $\mathrm{i} / \mathrm{ili}$ atopijski dermatitis, a $32 \%$ djece sa atopijskim dermatitisom je imalo i astmu ili alergijski rinitis. Oko $30 \%$ djece sa alergijskim rintisom bolovalo je i od atopijskog dermatitisa i /ili astme, što je u skladu sa našim rezulatima (10). Dokazano prisustvo sve tri atopijske bolesti kod pacijenata sa perzistentnom teškom astmom nedvojbeno čini kliničku sliku težom i teže postizanje kontrole bolesti, što $u$ konačnici utiče na kvalitet života (11). Važnu ulogu $\mathrm{u}$ razvoju atopijskih bolesti, naročito astme i alergijskog rinitisa, zauzima izloženost bolesnika unutrašnjim "indoor" i spoljašnjim "outdoor" alergenima. S p o r i k i saradnici su proveli prospektivnu studiju kojom je dokazano da djeca izložena visokim nivoima inhalatornih alergena $u$ ranoj životnoj dobi imaju veći rizik za razvoj senzibilizacije i simptoma astme. Višestruka senzibilizacija predstavlja prirodni tok alergije, u 
prilog tome govore studije Fascea i Ciprandina (12). Povišene koncentracije ukupnih $\operatorname{IgE}$ antitijela su $\mathrm{u}$ direktnoj korelaciji sa početkom i stepenom izloženosti alergenima te su vrijednosti IgE i stepen težine astme u uzročno-posljedičnoj vezi. Autori smatraju da određivanje ukupnog IgE u serumu ima prediktivnu vrijednost $\mathrm{u}$ procjeni stepena težine astme (13), što su pokzali i naši rezulati da pacijenti sa teškom astmom imaju statistički veću vrijednost IgE. Povišenu vrijednost hsCRP prvog dana je imalo $26,67 \%$ pacijenata, nakon trodnevne primjene terapije povišene koncentracije hsCRP značajno su se smanjile kod njih 13,33\% u odnosu prema vrijednostima prije liječenja, ali su te vrijednosti još uvijek bile iznad referentnih predviđenim za uzrast. Medijana vrijednosti hsCRP kod ispitanika sa teškom perzistentnom astmom je statistički značajno veća nego kod ispitanika sa ostalim stepenima težine astme. Naši rezultati su u skladu sa rezultatima drugih studijskih grupa, naime $\mathrm{u}$ istraživanju $\mathrm{N}$ a v r a t i 1 a i saradnika, ukazuju da raspon koncentracije hsCRP-a kod djece sa nekontrolisanom astmom, takođe je bio veći $(0,1-4,5 \mathrm{mg} / \mathrm{L})$ u odnosu na djecu sa kontrolisanom astmom $(0,12-0,97 \mathrm{mg} / \mathrm{L})$ [14]. Slične rezultate su objavili D o d i g i saradnici pri ispitivanju vrijednosti hsCRP-a kod djece sa akutnom egzacerbacijom astme. Oni su našli da su vrijednosti hsCRP-a kod te djece bile iznad referentnih vrijednosti za dob (medijan 4,8 $\mathrm{mg} / \mathrm{L}$ ), a nakon primjene salbutamola unutar referentnih vrijednosti (medijan 1,5 mg/L) [15]. Takođe, značajnu korelaciju između povišene vrijednosti $u$ serumu hsCRP i respiratornih simptoma kod pacijenata sa astmom su našli i $\mathrm{O} l$ a f s d o t t i r i saradnici. U svom istraživanju $\mathrm{T}$ a $\mathrm{k}$ e $\mathrm{m} \mathrm{u} \mathrm{r}$ i saradnici su opisali obrnutu korelaciju vrijednosti hsCRP i plućne funkcije bolesnika koji nisu bili na terapiji inhalatornim kortikosteroidima. Pomenuti autori su pokazali da su bolesnici bez terapije inhalatornim kortikosteroidima $(1,33 \pm 1,48 \mathrm{mg} / \mathrm{L})$ imali veću koncentraciju hsCRP-a u odnosu na zdrave ispitanike $(0,21 \pm 0,30 \mathrm{mg} / \mathrm{L}) \mathrm{i}$ ispitanike koji su bili na inhalatornoj kortikosteroidnoj terapiji $(0,90 \pm 1,00 \mathrm{mg} / \mathrm{L})$. Grupa izraelskih autora je provela istraživanje kod 63. djece uzrasta od 2-12 godina. Poredili su koncentraciju hsCRP-a u akutnoj egzacerbaciji astme i nakon primijenjene terapije, $\mathrm{i}$ utvrdili su da je koncentracija hsCRP-a značajno viša u akutnoj bolesti $(14,28 \pm 8,45 \mathrm{mg} / \mathrm{L})$ nego nakon terapije $(1,92 \pm 3,16 \mathrm{mg} / \mathrm{L})$, te da je koncentracija bila $\mathrm{u}$ direktnoj korelaciji sa vrijednostima FEV1. Takođe, pokazano je da su se vrijednosti hsCRP kod neke djece i nakon provedene terapije bile iznad referentnih vrijednosti za dob $(>2,8 \mathrm{mg} / \mathrm{L})$, što govori u prilog da veća koncentracija hsCRP-a ukazuje na veći stepen inflamacije $\mathrm{u}$ disajnim putevima kod djece sa astmom [16]. Iz navednog bismo mogli zaključiti da već prisutna alergijska inflamacija u disajnim putevima kod oboljelih od astme, u akutnom napadu, pokreće složenu interakciju upalnih ćelija, medijatora i citokina, koji indukuju sintezu hsCRP. $\mathrm{S}$ toga hsCRP, kao jednostavan test iz krvi koji je i relativno jeftin, bi mogao biti surogat marker inflamacije disajnih puteva [17].

Tabela 1.Prikaz kliničkih i laboratorijskih karakteristika pacijenata prema stepenima težine astme

\begin{tabular}{|c|c|c|c|c|c|c|}
\hline Parametar & $\begin{array}{l}\text { Stepen težine } \\
\text { astme }\end{array}$ & Broj & $\begin{array}{l}\text { Sr.vrijed } \\
(95 \% \mathrm{CI})\end{array}$ & $\begin{array}{l}\text { Minimum- } \\
\text { Maksimum }\end{array}$ & $\begin{array}{c}\text { Medijana } \\
\text { (interkvartilni } \\
\text { interval) }\end{array}$ & $p$ vrijednost \\
\hline \multirow{4}{*}{$\begin{array}{l}\text { Dob } \\
\text { (mjeseci) }\end{array}$} & Intermitentna & 5 & $\begin{array}{c}120.80 \\
(93.10-148.50)\end{array}$ & $84-161$ & $\begin{array}{c}122.0 \\
(96.0-141.0)\end{array}$ & \multirow{4}{*}{$\mathrm{p}=0.535$} \\
\hline & Perzistentna blaga & 8 & $\begin{array}{c}138.13 \\
(122.40-153.85)\end{array}$ & $108-168$ & $\begin{array}{c}139.5 \\
(116.5-158.5)\end{array}$ & \\
\hline & $\begin{array}{c}\text { Perzistentna } \\
\text { umjerena }\end{array}$ & 12 & $\begin{array}{c}122.58 \\
(107.55-137.61)\end{array}$ & $84-162$ & $\begin{array}{c}120.5 \\
(98.5-143.5)\end{array}$ & \\
\hline & Perzistentna teška & 5 & $\begin{array}{c}130.60 \\
(112.78-148.42)\end{array}$ & $109-160$ & $\begin{array}{c}133.0 \\
(114.0-137.0)\end{array}$ & \\
\hline \multirow{4}{*}{$\begin{array}{l}\text { Broj alergijskih } \\
\text { senzibilizacija }\end{array}$} & Intermitentna & 5 & $\begin{array}{c}2.20 \\
(1.06-3.34)\end{array}$ & $1.0-4.0$ & $\begin{array}{c}2.0 \\
(1.0-3.0) \\
\end{array}$ & \multirow{4}{*}{$\begin{array}{l}\mathrm{p}^{\mathrm{a}}=0.131 \\
\mathrm{p}^{\mathrm{b}}=0.030\end{array}$} \\
\hline & Perzistentna blaga & 8 & $\begin{array}{c}3.63 \\
(2.40-4.85)\end{array}$ & $1.0-6.0$ & $3.5(2.5-5.0)$ & \\
\hline & $\begin{array}{c}\text { Perzistentna } \\
\text { umjerena }\end{array}$ & 12 & $\begin{array}{c}3.08 \\
(2.42-3.74) \\
\end{array}$ & $1.0-5.0$ & $3.0(2.5-3.5)$ & \\
\hline & Perzistentna teška & 5 & 4.20 & $3.0-6.0$ & $4.0(4.0-4.0)$ & \\
\hline
\end{tabular}




\begin{tabular}{|ccccccc|}
\hline & \multicolumn{5}{c}{$(3.24-5.16)$} \\
\hline & Intermitentna & 5 & $\begin{array}{c}508.82 \\
(134.73-882.91)\end{array}$ & $69.1-1052.0$ & $\begin{array}{c}445.0 \\
(146.0-832.0)\end{array}$ \\
\cline { 2 - 6 } Ukupni Ig E (kU/L) & Perzistentna blaga & 8 & $\begin{array}{c}446.88 \\
(271.64-622.11)\end{array}$ & $213.0-841.0$ & $\begin{array}{c}332.0 \\
(262.5-662.5)\end{array}$ & $\mathrm{p}=0.035$ \\
\cline { 2 - 6 } & $\begin{array}{c}\text { Perzistentna } \\
\text { umjerena }\end{array}$ & 12 & $\begin{array}{c}461.98 \\
(262.34-661.61)\end{array}$ & $46.7-1132.0$ & $\begin{array}{c}427.0 \\
(167.0-727.50)\end{array}$ \\
\cline { 2 - 6 } & Perzistentna teška & 5 & $\begin{array}{c}1535.0 \\
(160.97-2909.03)\end{array}$ & $591.0-4282.0$ & $\begin{array}{c}738.0 \\
(678.0-1386.0)\end{array}$
\end{tabular}

\section{$p^{b}$ intermitentna perzistentna}

\begin{tabular}{|c|c|c|c|c|c|c|}
\hline Parametar & Stepen težine astme & Broj & $\begin{array}{l}\text { Sr.vrijed } \\
(95 \% \mathrm{CI}) \\
\end{array}$ & $\begin{array}{l}\text { Minimum- } \\
\text { Maksimum }\end{array}$ & \begin{tabular}{|c|}
$\begin{array}{c}\text { Medijana (interkvartilni } \\
\text { interval) }\end{array}$ \\
\end{tabular} & $p$ vrijednost \\
\hline \multirow{4}{*}{$\begin{array}{l}\text { hsCRP } \\
(\mathrm{mg} / \mathrm{l})\end{array}$} & Intermitentna & 5 & $\begin{array}{c}0.89 \\
(0.00-1.86) \\
\end{array}$ & $0.31-2.87$ & $\begin{array}{c}0.40 \\
(0.36-0.53) \\
\end{array}$ & \multirow{4}{*}{$\mathrm{p}=0.009$} \\
\hline & Perzistentna blaga & 8 & $\begin{array}{c}0.34 \\
(0.21-0.47) \\
\end{array}$ & $0.13-0.69$ & $\begin{array}{c}0.36 \\
(0.17-0.69) \\
\end{array}$ & \\
\hline & $\begin{array}{c}\text { Perzistentna } \\
\text { umjerena }\end{array}$ & 12 & $\begin{array}{c}0.87 \\
(0.29-1.44) \\
\end{array}$ & $0.09-2.91$ & $\begin{array}{c}0.43 \\
(0.20-1.10)\end{array}$ & \\
\hline & Perzistentna teška & 5 & $\begin{array}{c}5.37 \\
(1.97-8.77)\end{array}$ & $2.82-12.10$ & $\begin{array}{c}4.08 \\
(2.83-5.02) \\
\end{array}$ & \\
\hline \multirow{4}{*}{$\begin{array}{l}\text { hsCRP } \\
(\mathrm{mg} / \mathrm{l})\end{array}$ treći dan } & Intermitentna & 5 & $\begin{array}{c}0.34 \\
(0.25-0.42)\end{array}$ & $0.21-0.43$ & $\begin{array}{c}0.35 \\
(0.28-0.40)\end{array}$ & \multirow{4}{*}{$\mathrm{p}<0.001$} \\
\hline & Perzistentna blaga & 8 & $\begin{array}{c}0.25 \\
(0.17-0.33)\end{array}$ & $0.10-0.37$ & $\begin{array}{c}0.29 \\
(0.14-0.34) \\
\end{array}$ & \\
\hline & $\begin{array}{c}\text { Perzistentna } \\
\text { umjerena }\end{array}$ & 12 & $\begin{array}{c}0.33 \\
(0.21-0.46) \\
\end{array}$ & $0.10-0.75$ & $\begin{array}{c}0.35 \\
(0.14-0.42) \\
\end{array}$ & \\
\hline & Perzistentna teška & 5 & $\begin{array}{c}1.99 \\
(0.79-3.19) \\
\end{array}$ & $0.63-3.80$ & $\begin{array}{c}1.92 \\
(0.72-2.86) \\
\end{array}$ & \\
\hline \multirow{4}{*}{ FVC (\%) } & Intermitentna & 5 & $\begin{array}{c}77.18 \\
(68.74-85.62) \\
\end{array}$ & $67.0-92.0$ & $\begin{array}{c}74.0 \\
(72.20-80.70) \\
\end{array}$ & \multirow{4}{*}{$\mathrm{p}=0.012$} \\
\hline & Perzistentna blaga & 8 & $\begin{array}{c}78.80 \\
(71.0-86.60) \\
\end{array}$ & $62.0-100.0$ & $\begin{array}{c}79.50 \\
(71.70-83.0) \\
\end{array}$ & \\
\hline & $\begin{array}{c}\text { Perzistentna } \\
\text { umjerena }\end{array}$ & 12 & $\begin{array}{c}79.92 \\
(73.45-86.38) \\
\end{array}$ & $68.0-106.0$ & $\begin{array}{c}75.0 \\
(72.0-84.0) \\
\end{array}$ & \\
\hline & Perzistentna teška & 5 & $\begin{array}{c}64.10 \\
(58.47-69.73) \\
\end{array}$ & $53.0-69.50$ & $\begin{array}{c}66.0 \\
(65.0-67.0) \\
\end{array}$ & \\
\hline \multirow{4}{*}{ FEV1 (\%) } & Intermitentna & 5 & $\begin{array}{c}82.60 \\
(72.91-92.29)\end{array}$ & $71.0-94.0$ & $\begin{array}{c}81.0 \\
(73.0-94.0)\end{array}$ & \multirow{4}{*}{$\mathrm{p}=0.019$} \\
\hline & Perzistentna blaga & 8 & $\begin{array}{c}83.64 \\
(75.29-91.99)\end{array}$ & $72.0-107.0$ & $\begin{array}{c}80.50 \\
(74.05-90.50) \\
\end{array}$ & \\
\hline & $\begin{array}{c}\text { Perzistentna } \\
\text { umjerena }\end{array}$ & 12 & $\begin{array}{c}88.75 \\
(81.33-96.17) \\
\end{array}$ & $73.0-115.0$ & $\begin{array}{c}82.0 \\
(80.0-100.0)\end{array}$ & \\
\hline & Perzistentna teška & 5 & $\begin{array}{c}67.04 \\
(59.54-74.54)\end{array}$ & $55.20-78.0$ & $68.0(63.0-71.0)$ & \\
\hline
\end{tabular}

Tabela 2. Osnovni pokazatelji deskriptivne statistike za broj alergijskih senzibilizacija, drugih atopijskih bolesti i plućnih funkcija kod pacijenta sa povišenim hsCRP

\begin{tabular}{|c|c|c|c|c|c|c|c|}
\hline Parametar & hsCRP & Broj & $\begin{array}{l}\text { Sr.vrijed } \\
(95 \% \mathrm{CI})\end{array}$ & $\begin{array}{l}\text { Minimum- } \\
\text { Maksimum }\end{array}$ & Medijana (interkvartilni interval) & $\begin{array}{c}p \\
\text { vrijednost }\end{array}$ & $\begin{array}{c}\text { Korelacija } \\
\text { r } \\
\text { (p) }\end{array}$ \\
\hline \multirow{2}{*}{ Broj alergijskih senzibilizacija } & RV & 22 & $\begin{array}{c}3.18 \\
(2.63-3.74)\end{array}$ & $1.0-6.0$ & $\begin{array}{c}3.0 \\
(2.0-4.0)\end{array}$ & \multirow{2}{*}{$\mathrm{p}=0.601$} & \multirow{2}{*}{$\begin{array}{l}r=0.198 \\
p=0.293\end{array}$} \\
\hline & Povišen & 8 & $\begin{array}{c}3.50 \\
(2.27-4.73)\end{array}$ & $1.0-6.0$ & $\begin{array}{c}4.0 \\
2.0-4.0)\end{array}$ & & \\
\hline
\end{tabular}




\begin{tabular}{|c|c|c|c|c|c|c|c|}
\hline \multirow{2}{*}{ Broj drugih atopijskih bolesti } & RV & 22 & $\begin{array}{c}1.14 \\
(0.81-1.46)\end{array}$ & $0.00-3.00$ & $\begin{array}{c}1.00 \\
(1.00-2.00) \\
\end{array}$ & \multirow{2}{*}{$\mathrm{p}=0.028$} & \multirow{2}{*}{$\begin{array}{l}\mathrm{r}=0.367 \\
\mathrm{p}=0.046\end{array}$} \\
\hline & Povišen & 8 & $\begin{array}{c}2.00 \\
(1.36-2.64)\end{array}$ & $1.00-3.00$ & $\begin{array}{c}2.00 \\
(1.00-3.00)\end{array}$ & & \\
\hline \multirow[b]{2}{*}{ FVC (\%) } & RV & 22 & $\begin{array}{c}80.01 \\
(75.45-84.58) \\
\end{array}$ & $62.00-106.00$ & $\begin{array}{c}79.50 \\
(72.00-84.00) \\
\end{array}$ & \multirow{2}{*}{$\mathrm{p}=0.004$} & \multirow{2}{*}{$\begin{array}{l}\mathrm{r}=-0.574 \\
\mathrm{p}<0.001\end{array}$} \\
\hline & Povišen & 8 & $\begin{array}{c}66.94 \\
(62.36-71.51) \\
\end{array}$ & $53.00-74.00$ & $\begin{array}{c}67.00 \\
(65.50-71.75) \\
\end{array}$ & & \\
\hline \multirow{2}{*}{ FEV1 (\%) } & RV & 22 & $\begin{array}{c}86.64 \\
(81.26-92.02) \\
\end{array}$ & $71.00-115.00$ & $\begin{array}{c}83.00 \\
(74.10-95.00) \\
\end{array}$ & \multirow{2}{*}{$\mathrm{p}=0.007$} & \multirow{2}{*}{$\begin{array}{l}\mathrm{r}=-0.446 \\
\mathrm{p}=0.013\end{array}$} \\
\hline & Povišen & 8 & $\begin{array}{c}72.03 \\
(65.48-78.57) \\
\end{array}$ & $55.20-81.00$ & $\begin{array}{c}74.50 \\
(65.50-80.00) \\
\end{array}$ & & \\
\hline
\end{tabular}

\section{ZAKLJUČAK}

Istraživanje je pokazalo da su vrijednosti hsCRP $\mathrm{u}$ serumu kod pacijenata $\mathrm{u}$ akutnoj egzacerbaciji astme u direktnoj korelaciji sa stepenom atopijskog statusa, što je viši stepen atopijskog statusa to su vrijednosti hsCRP bile više. Tom činjenicom naglašava se pitanje postojanja sistemske upale $u$ astmi kao bolesti koja prema definiciji podrazumijeva hroničnu inflamaciju disajnih puteva. Evidentno je da bi se hsCRP mogao koristiti kao nespecifičnog biomarker upale kod djece u akutnoj egzacerbaciji astme, te kao pokazatelj uspješnosti terapije.

\section{REFERENCE}

1. Cowan K, Guilbert TW. Pediatric asthma phenotypes. Curr Opin Pediatr. 2012; 24(3):344-51.

2. Ledue TB, Rifai N. Preanalytic and analytic sources of variations in C-reactive protein measurement: implications for cardiovascular disease risk assessment. [Review] Clin Chem 2003; 49: 1258-71.

3. Schlebusch H, Liappis N, Kalina E, Klein G. High sensitive CRP and creatinine reference intervals from infancy to childhood. Lab Med 2002; 26:341-6.

4. World Medical Association Declaration of HelsinkiEthical Principles for Medical Research Involving Human http://www.wma.net/e/policy/b3.htm.

5. EPR-3. Expert Panel Report: Guidelines for the Diagnosis and Management of Asthma. Full Report 2007. HIH Publication No 07-4051. Bethesda, MD: U.S. Department of Health and Human Services; National Institutes of Health; National Heart, Lung, and Blood Institute; National Asthma Education and Prevention Program, August 2007.

6. Dodig S, Richter D, Benko B, Živčić J, Raos, et al. Cut-off Values of Total Serum IgE Between
Nonatopic and Atopic Children in North-West Croatia. Clin Chem Lab Med 2006; 44:639-647.

7. Gissler M, Jarvelin MR, Louhiala P, Hemminki E. Boys have more health problems in childhood than girls: follow-up of the 1987 Finnish birth cohort. Acta Paediatr 1999; 88:310-314.

8. Bonds RS, Horiuti TM. Estrogen effects in allergy and asthma. Curr Opin Allergy Clin Immunol 2013; 13(1):92-99.

9. The International Study of Asthma and Allergies in Childhood (ISAAC) Steering Committee. Worldwide variations in the prevalence of asthma symptoms: the International Study of Asthma and Allergies in Childhood (ISSAC). Eur Respir J 1998; 12:315-35.

10. Aberg N, Egstrom I. Natural history of allergic diseases in children. Acta Pediatr Scand 1990; 79(2):206-11.

11. Ballardini N, Kull I, Lind T, Hallner E, Almqvist C, Ostblom E, Melén E, Pershagen G, Lilja G, Bergström A, Wickman M. Development and comorbidity of eczema, asthma and rhinitis to age 12: data from the BAMSE birth cohort. Allergy 2012; 67(4):537-44.

12. Fasce L, Tosca MA, Olcese R, Milanese M, Erba D, Ciprandi G. The natural history of allergy: the development of new sensitizations in asthmatic children. Immunol Lett 2004; 93(1): 45-50.

13. Satwani H, Rehman A, Ashraf S, Hassan A. Is serum total IgE levels a good predictor of allergies in children? J Pak Med Assoc 2009; 59(10):698-702.

14. Navratil M, Plavec D, Dodig S, Jelcic Z, Nogalo B, Erceg D, Turkalj M. Markers of systemic and lung inflammation in childhood asthma. J Asthma 2009; 46(8):822-8.

15. Dodig S, Cepelak I, Raos M, Zrinski Topic R, Zivcic J, Pavic I. Concentration of C-reactive protein, magnesium and calcium in children with acute bronchoconstriction before and after therapy with salbutamol. Biochem Med 2010; 20(2):242-48. 
16. Takemura $M$, Matsumoto $H$, Niimi A, Ueda $T$, Matsuoka H, Yamaguchi M, Jinnai M, Mauro S, Hirai T, Ito Y, Nakamuro T, Mio T, Chin K, Mishima M. High sensitivity C-reactive protein in asthma. Eur Respir J 2006; 27:908-12.
17. Razi E, Ehteram H, Akbari H, Chavoshi V, Razi A. Evaluation of High-Sensitivity C-Reactive Protein in Acute Asthma. Tanaffos. 2012; 11(1): 32-37.

INTRODUCTION: Asthma is a syndrome characterized by chronic inflammation of the airways which is one of the key elements of the disease. According to the results of the research in the field of allergology, it seems that the determination of non-specific inflammation biomarker of highly sensitive $C$ reactive protein ( $h \mathrm{SCRP}$ ), would enable the assesment of the level or degree of inflammation of the airways in asthma patients, both in adults and in children. Significant correlation between the increased concentration of CRP and respiratory symptoms such as wheezing and dyspnea after exertion and nighttime cough in children with acute exacerbations of asthma is demonstrated.

OBJECTIVE: To determine whether hsCRP levels correlate with the severity and length of the asthma attack, and whether the monitoring of hSCRP can be a good indicator of sucess (or failure) of treatment of acute exacerbations of asthma in children.

MATERIAL AND METHODS: The study included 30 children, aged 7 to 14 years (boys and girls) hospitalized for treatment of acute asthma attacks. Treatment is carried out by inhale therapy of beta-2agonists and anticholinergics, fast-acting, in case of incomplete effect of initial application of the beta-2 agonist (moderate or severe attack) there were systemic corticosteroids included. To determine the hsCRP level, the patients' serum was taken before treatment and three days after treatment. HsCRP concentration was determined by immunoturbidimetric method on latex particles on biochemical analyzer Olympus AU 680.

RESULTS: Increased values of hsCRP on the first day had $26.67 \%$ of patients, after three days of therapy elevated concentrations of hSCRP have significantly reduced in $13.33 \%$ of them, compared to the values before the treatment. The median value of hSCRP in the patients with severe persistent asthma is statistically significantly higher than in patients with other degrees of severity of asthma.

CNCLUSION: The results of this research have shown that the value of hSCRP in serum in patients with the acute exacerbation of asthma is directly correlated with the atopic status, the higher the degree of atopic status - higher the values of hsCRP. This fact highlights the issue of the existence of systemic inflammation in asthma as a disease which by definition involves chronic inflammation of the airways. It is evident that hsCRP can be used as non-specific biomarker of inflammation in children with asthma, as well as an indicator of the success of therapy.

Keywords: children, asthma, hsCRP.

Olivera Ljuboja

Klinika za dječije bolesti.

Univerzitetski Klinički centar Republike Srpske

Mob. 065527098

e-mail: olivera.ljuboja@gmail.com 